\title{
Bacterial-Mediated Induced Resistance in Cucumber: Beneficial Effect of the Endophytic Bacterium Serratia plymuthica on the Protection Against Infection by Pythium ultimum
}

\author{
Nicole Benhamou, Serge Gagné, Dominique Le Quéré, and Leila Dehbi
}

First author: Recherche en Sciences de la vie et de la santé, Pavillon Charles-Eugène Marchand, Université Laval, Sainte-Foy, Québec, Canada, G1K 7P4; and second, third, and fourth authors: Premier Tech ltée, 1 Avenue Premier, C.P. 3500, Rivière-du-Loup, Québec, Canada, G5R 4C9. Accepted for publication 30 September 1999.

\begin{abstract}
Benhamou, N., Gagné, S., Le Quéré, D., and Dehbi, L. 2000. Bacterialmediated induced resistance in cucumber: Beneficial effect of the endophytic bacterium Serratia plymuthica on the protection against infection by Pythium ultimum. Phytopathology 90:45-56.

The potential of the endophytic bacterium Serratia plymuthica strain R1GC4 in stimulating defense reactions in cucumber (Cucumis sativus) seedlings inoculated with the soilborne pathogen Pythium ultimum was explored at the cellular level. Bacterial treatment prior to Pythium inoculation resulted in less seedling disease development as compared with that in nontreated control plants, in which typical root symptoms were visible by 3 days after inoculation with the pathogen. Histological investigations of root samples revealed striking differences in the extent of plant defense reactions between bacterized and nonbacterized plants. These observations were further confirmed at the ultrastructural level with the demonstration that restriction of fungal colonization to the outermost root tissues of bacterized seedlings correlated with the deposition of enlarged callose-enriched wall appositions at sites of potential pathogen penetration and the accumulation of an osmiophilic material in the colonized areas.
\end{abstract}

ABSTRACT

The work on induced resistance over the past decade has led to a remarkable awareness of the pivotal role being played by some microbial agents in stimulating defense gene expression and disease resistance in plants $(9,10,14,35)$. From these fundamental studies, it has become realistic that sensitizing a plant to respond more rapidly to infection could confer increased protection against virulent pathogens (29). One of the most promising options in the context of microbially mediated induced resistance concerns the use of selected bacterial endophytes as potential elicitors of plant defense mechanisms (35). Surprisingly, the role played by these endophytes was not fully appreciated until recent years, although reduction of disease incidence and severity following soil amendment with some Pseudomonas and Bacillus strains was often observed $(18,22)$. Recent progress in the purification and identification of antifungal metabolites has led to the consideration that plant protection against virulent pathogens relied, at least partly, on the production of bacterial antibiotics $(23,26)$, associated with a possible competition for nutrients and iron in the rhizosphere (2). Despite the increasing amount of research devoted to the antimicrobial activity of some bacterial endophytes, our knowledge

Corresponding author: N. Benhamou; E-mail address: nben@rsvs.ulaval.ca

* The $e$-Xtra logo stands for "electronic extra" and indicates the HTML abstract available on-line contains supplemental material not included in the print edition. Figures 1 and 2 are in color on-line.

Publication no. P-1999-1115-03R

(C) 2000 The American Phytopathological Society
Hyphae of the pathogen, surrounded by this electron-opaque material, exhibited considerable changes including cytoplasm disorganization and, in many cases, loss of the protoplasm. However, labeling with the $\beta$-1,4exoglucanase resulted in a regular labeling of Pythium cell walls, even at a time when these walls were entirely coated by the osmiophilic material. This material was also found to infiltrate into the invading hyphae to form either an internal coating of the cell wall or a network of polymorphic droplets in the area previously occupied by the cytoplasm. Cytochemical investigations revealed that callose, pectin, and cellulose appeared in the wall appositions. In addition, glucosides, lipids, and phenolics were detected in the electron-dense aggregates forming the core of most wall appositions. Finally, galactose residues were among the minor polysaccharidic compounds detected in the wall appositions. Evidence is provided in this study showing that treatment with $S$. plymuthica sensitizes susceptible cucumber plants to react more rapidly and more efficiently to Pythium attack through the formation of physical and chemical barriers at sites of potential fungal entry.

Additional keywords: biological control, gold cytochemistry. regarding the involvement of the plant itself in the observed reduction of disease incidence is still elusive, although an increasing number of reports indicate that bacterially mediated induced resistance is likely a crucial event in the complex process of disease protection $(35,38)$.

A number of endophytic bacteria have been shown to increase protection against fungal infection by promoting marked host metabolic changes including production of phytoalexins (36), accumulation of pathogenesis-related proteins (39), and deposition of structural barriers $(1,9,10)$. The mechanisms by which these bacteria may provide biological control against soilborne pathogens are selective, probably because a strong heterogeneity in both the nature and the extent of defense reactions exists among plant species (10). Benhamou et al. $(10,14)$ recently demonstrated that pea and tomato root bacterization with Pseudomonas fluorescens strain 6328R or Bacillus pumilus strain SE34 triggered a set of plant defense reactions that resulted in the elaboration of permeability barriers and in the creation of a fungitoxic environment that protected the roots by restricting pathogen growth to the outermost tissues. Evidence was provided from these studies showing that disease suppression was a multifaceted process that not only requires the synergistic contribution of several mechanisms such as antibiosis and induction of plant defense reactions, but also takes into account the intricate relationship established between the plant and the pathogen species.

A disease that has been the focus of much interest as a model host-pathogen system in both basic and applied research is cucumber root rot caused by the fungus Pythium ultimum Trow (20). 
Over the past few years, a number of descriptive studies have documented that selected rhizobacterial strains including Pseudomonas and Serratia spp. could exert beneficial effects on the protection of cucumber plants against Pythium-incited diseases $(31,33)$. Considering the few options offered to producers to overcome Pythiumincited diseases in greenhouse productions (32), the current study was undertaken to explore the potential of the endophytic bacterium Serratia plymuthica strain R1GC4 at controlling Pythium root rot of greenhouse-grown cucumber. The objectives of the current research were, first, to investigate ultrastructurally the outcome of the cucumber-Pythium interaction upon bacterial treatment and, second, to delineate the cytological and biochemical changes associated with fungal restriction in planta. Evidence is provided showing that cucumber root cells undergo significant ultrastructural and biochemical modifications that correlate with the deposition of a phenolic-enriched occluding material and the formation of structural barriers that likely prevent pathogen ingress toward the vascular stele.

\section{MATERIALS AND METHODS}

Bacterial culture and growth conditions. S. plymuthica (strain R1GC4), obtained from Agrium Inc., Saskatoon, Saskatchewan, Canada, was stored in nutrient broth containing $10 \%$ glycerol at $-80^{\circ} \mathrm{C}$. To produce bacterial cells for root inoculation, the bacterial strain was retrieved from storage, streaked on King's B agar, and incubated for $48 \mathrm{~h}$. Inoculum was prepared by diluting bacterial suspensions with $0.1 \mathrm{M} \mathrm{MgSO}_{4}$ to obtain a final concentration of approximately $10^{8} \mathrm{CFU} / \mathrm{ml}$.

Fungal culture and growth conditions. The root pathogen $P$. ultimum isolate BARR 447 (Center for the Land and Resources Research, Ottawa, Ontario, Canada), known to be virulent for several crops including cucumber and pea, was routinely grown on potato dextrose agar (PDA) (Difco Laboratories, Detroit) in a dark incubator at $26^{\circ} \mathrm{C}$.

Plant treatment with $S$. plymuthica and fungal pathogen inoculation. Seeds of cucumber (Cucumis sativus L. cv. Corona; De Ruiter Seeds Inc., Columbus, OH) were surface-sterilized by immersion in $1 \%$ aqueous sodium hypochlorite for $60 \mathrm{~min}$ and thoroughly rinsed in sterile distilled water. They were directly soaked in $50 \mathrm{ml}$ of the bacterial suspension $\left(10^{8} \mathrm{CFU} / \mathrm{ml}\right)$ for $12 \mathrm{~h}$ and allowed to germinate in petri dishes containing sterile moist cotton. Plates were incubated at $25^{\circ} \mathrm{C}$ in the dark for $48 \mathrm{~h}$. Germinated seeds were carefully removed from the cotton and sown in a mixture of peat-perlite-vermiculite $(1: 1: 1)$ at a density of four seedlings per $6-\mathrm{cm}$ pot. Controls included untreated germinated seeds sown as described above. Plants were fertilized every other day with a nutrient solution as previously described (8). The $\mathrm{pH}$ of the solution was adjusted to 6.2 and the electrical conductivity to $2.4 \mathrm{mS}$. Seedlings were grown on a glasshouse bench at 24 to $26^{\circ} \mathrm{C}$ with $16 \mathrm{~h}$ of light supplemented by high-pressure sodium lamps $\left(100 \mu \mathrm{E} \mathrm{m}^{-2} \mathrm{~s}^{-1}\right)$.

Cucumber seedlings at the one- to two-leaf stage were challengeinoculated by introducing two plugs $(5 \mathrm{~mm}$ diameter) of actively growing mycelium of $P$. ultimum as close as possible to the root system. Control plants were treated with fungus-free PDA disks.
Ten plants were used for each treatment, and the experiment was repeated twice. The roots were pulled out of the substrate and examined daily for fungal infection (visible necrotic lesions). For electron microscope investigations, samples from the main roots were collected 5 days after fungal inoculation.

Tissue processing for ultrastructural observations. Samples $\left(2 \mathrm{~mm}^{3}\right)$, collected from the crown and main root at potential sites of fungal entry (necrotic lesions), were fixed by immersion in $3 \%$ ( $\mathrm{vol} / \mathrm{vol}$ ) glutaraldehyde in $0.1 \mathrm{M}$ sodium cacodylate buffer, $\mathrm{pH} 7.2$, at $4{ }^{\circ} \mathrm{C}$ overnight and postfixed with $1 \%(\mathrm{wt} / \mathrm{vol})$ osmium tetroxide in the same buffer for $1 \mathrm{~h}$ at $4^{\circ} \mathrm{C}$. Root samples were dehydrated in a graded ethanol series and embedded in Epon 812. Thin sections $(0.7 \mu \mathrm{m})$, cut from the Epon-embedded material using glass knives, were mounted on glass slides and stained with $1 \%$ aqueous toluidine blue prior to examination with a Zeiss Axioscope microscope (Carl Zeiss Canada, Don Mills, Ontario, Canada). Ultrathin sections $(0.1 \mu \mathrm{m})$, collected on nickel grids using a diamond knife, were either contrasted with uranyl acetate and lead citrate for immediate examination with a JEOL 1200 EX transmission electron microscope (JEOL, Ltd., Tokyo) operating at $80 \mathrm{kV}$ or further processed for cytochemical labeling. For each treatment, an average of five samples from five different roots was investigated. For each sample, 10 to 15 ultrathin sections were examined under the electron microscope.

Preparation of the gold-complexed probes. Colloidal gold with particles averaging $15 \mathrm{~nm}$ in diameter was prepared according to Frens (24). As previously described (4), the $\mathrm{pH}$ of the colloidal gold solution was adjusted according to the isoelectric point of each enzyme and lectin used (Table 1). The Aplysia gonad lectin (AGL) (13), Ricinus communis agglutinin $\left(\mathrm{R}_{\mathrm{c}} \mathrm{A}\right)(12), \beta-1,4$-exoglucanase (11), $\beta$-glucosidase (3), $\beta$-1,3-glucanase from tobacco (5), and lipase (6) were directly complexed to colloidal gold at the appropriate $\mathrm{pH}$ (Table 1). Localization of lignin-associated phenolic compounds was performed by using a laccase (EC 1.10.3.2) purified from the white rot fungus Rigidoporus lignosus (27). The enzyme was complexed to colloidal gold at $\mathrm{pH} 4.0$, a $\mathrm{pH}$ value close to its isoelectric point reported to be 3.83 (15). All gold-conjugated probes were stored at $4^{\circ} \mathrm{C}$ and centrifuged at $4,050 \times g$ for 2 min before use.

Cytochemical labeling. Ultrathin sections were first floated for 5 min on a drop of $0.01 \mathrm{M}$ sodium phosphate-buffered saline (PBS) containing $0.02 \%$ of polyethylene glycol (PEG) 20,000 at the $\mathrm{pH}$ corresponding to the optimal activity of the protein tested (Table 1). Sections were then transferred to a drop of each gold-complexed probe for 30 to $60 \mathrm{~min}$ at room temperature in a moist chamber. They were washed thoroughly with PBS, $\mathrm{pH} 7.4$, rinsed with distilled water, and allowed to dry before staining with uranyl acetate and lead citrate.

Specificity of the different labelings was assessed by the following control tests: (i) addition of the corresponding substrate to each protein-gold complex for a competition experiment (polygalacturonic acids [ $1 \mathrm{mg} \mathrm{ml}^{-1}$ ] for the AGL-gold complex; D-galactose $\left[1 \mathrm{mg} \mathrm{ml}^{-1}\right.$ ] for the $\mathrm{R}_{\mathrm{c}} \mathrm{A}$-gold complex; $\beta$-1,4-glucans from barley $\left[1 \mathrm{mg} \mathrm{ml}^{-1}\right]$ for the $\beta$-1,4-exoglucanase-gold complex; salicin [1 $\left.\mathrm{mg} \mathrm{ml}^{-1}\right]$ for the $\beta$-glucosidase-gold complex; laminarin [1 $\mathrm{mg} \mathrm{ml}^{-1}$ ] for the $\beta$-1,3-glucanase; $p$-coumaric acid, ferulic acid, or sinapinic

TABLE 1. List of lectins and enzymes and optimal conditions for complex formation

\begin{tabular}{|c|c|c|c|c|}
\hline Lectin enzyme & Source & Substrate specificity & $\begin{array}{l}\mathrm{pH} \text { of colloidal gold } \\
\text { or conjugation }\end{array}$ & $\begin{array}{l}\mathrm{pH} \text { of pellet resuspension } \\
\text { and section incubation }\end{array}$ \\
\hline Aplysia gonad lectin (AGL) & Aplysia depilans & Polygalacturonic acids & 9.0 & 7.0 \\
\hline Ricinus communis agglutinin $\left(\mathrm{R}_{\mathrm{c}} \mathrm{A}\right)$ & Caster oil plant & D-galactose & 8.0 & 6.0 \\
\hline$\beta$-1,3-glucanase & Tobacco & $\beta-1,3$ glucans & 5.5 & 6.0 \\
\hline$\beta$-1,4-exoglucanase & Trichoderma harzianum & $\beta$-1,4-glucans & 9.0 & 6.0 \\
\hline$\beta$-glucosidase & Almonds & $\beta$-D-glucosides & 9.3 & 6.0 \\
\hline Laccase & Rigidoporus lignosus & Phenolics & 4.0 & 6.0 \\
\hline Lipase & Wheat germ & Triglycerides & 5.2 & 6.0 \\
\hline
\end{tabular}


acid $\left[1 \mathrm{mg} \mathrm{ml}^{-1}\right]$ for the laccase; and triacetin $\left[1 \mathrm{mg} \mathrm{ml}^{-1}\right]$ for the lipoprotein lipase); (ii) substitution of the protein-gold complex under study by the bovine serum albumin-gold complex to assess the nonspecific adsorption of the protein-gold complex to the tissue sections; (iii) incubation of the tissue sections with the proteingold complexes under nonoptimal conditions for biological activity; and (iv) incubation of the tissue sections with colloidal gold alone to assess the nonspecific adsorption of the gold particles to the tissue sections.

\section{RESULTS}

Symptomatology. Cucumber seedlings treated or not with $S$. plymuthica strain R1GC4 were inoculated with P. ultimum to determine their susceptibility to fungal attack (Fig. 1). Typical root symptoms, characterized by the formation of brownish lesions, were visible by 3 days after inoculation in control plants derived from untreated seeds. Between 4 and 5 days postinoculation, these plants showed severe symptoms of root rot and wilting
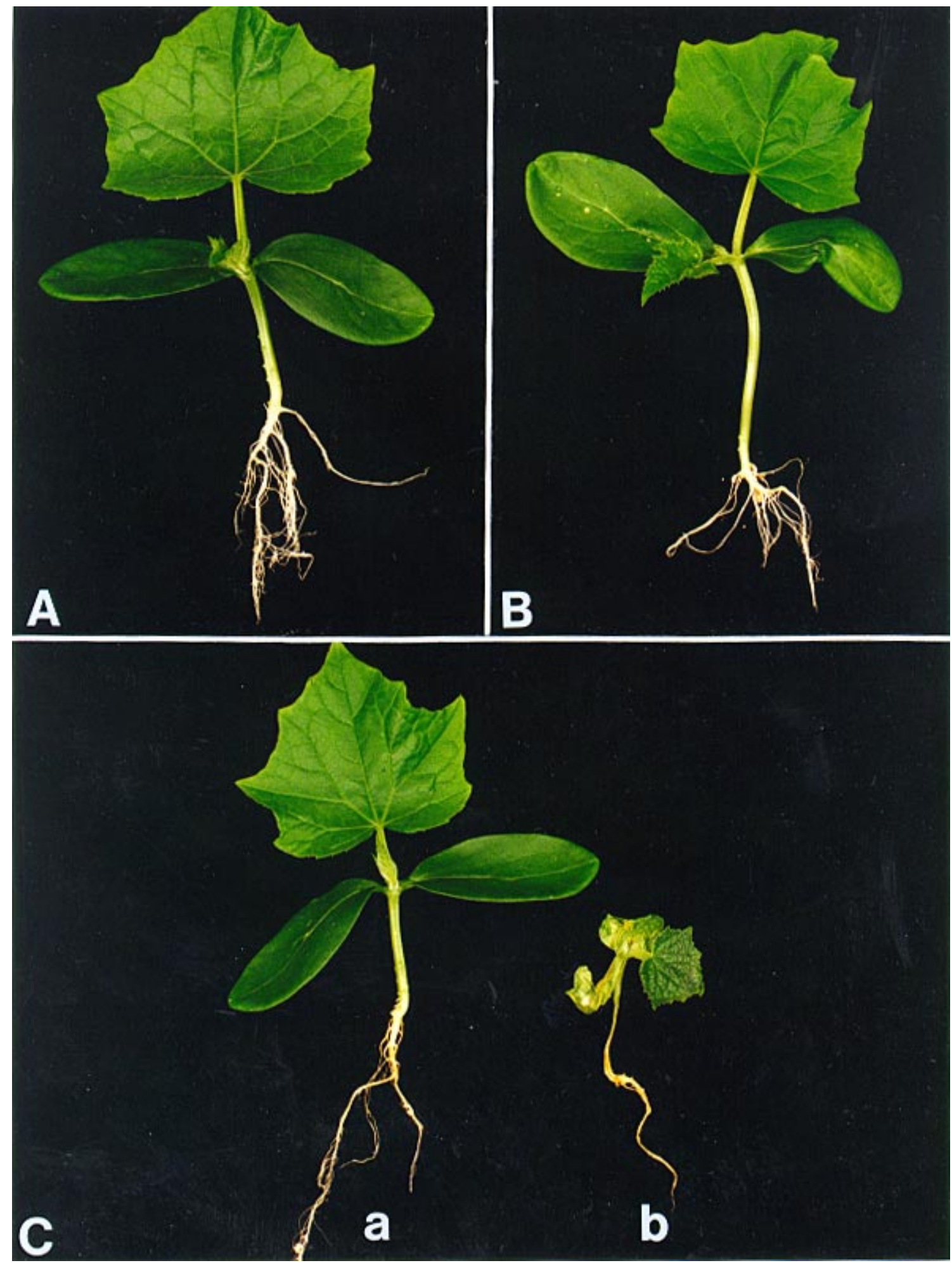

Fig. 1. Effect of seed treatment with Serratia plymuthica on the development of symptoms caused by Pythium ultimum in cucumber seedlings. A, Absence of bacterial treatment and fungal inoculation (healthy control). B, Bacterial treatment and absence of fungal inoculation (S. plymuthica alone). C, Fungal inoculation in the presence (a) or the absence (b) of bacterial treatment. 
(Fig. 1C, b). Most of them were dead by 7 to 8 days after fungal inoculation.

Bacterial treatment of the seeds prior to Pythium inoculation resulted in less seedling disease development than occurred with nontreated seeds (Fig. 1C, a). By 5 days after fungal inoculation, seedlings derived from Serratia-treated seeds were free of apparent symptoms such as wilting or senescence and exhibited a reduced number of root lesions (Fig. 1C, a; Table 2). Although some lesions could be seen on the lateral roots, their frequency and size never reached levels similar to those observed in control plants.

At that stage of plant growth, no difference in terms of overall plant growth as well as leaf size, shape, and color was observed among noninoculated plants whether they were produced from Serratia-free (Fig. 1A) or Serratia-treated seeds (Fig. 1B).

Histological observations. Observations of transversally sectioned roots from bacteria-free plants that were inoculated with $P$. ultimum (control) showed a pattern of fungal colonization similar to that described in earlier reports (20). By 5 days after fungal inoculation, root tissues were intensely colonized as evidenced by the occurrence of Pythium hyphae through much of the cortex, the endodermis, the paratracheal parenchyma cells, and even the vascular stele (Fig. 2A; Table 3). Pathogen ingress toward the vascular stele coincided with extensive cell disorganization such as cytoplasm breakdown and host cell wall alterations, as illustrated by the marked decrease in staining intensity of the wall structures (Fig. 2A, arrows). Host reactions such as wall appositions, intercellular plugging, and xylem vessel coating were not detected. In all cases, the observed pattern of host cell disorganization and host cell wall disruption coincided with the occurrence of macroscopically visible lesions along the main and lateral roots that exhibited marked loss of firmness (Fig. 1; Table 2).

Examination of root sections from Serratia-treated plants that were not challenged with $P$. ultimum showed that bacteria grew actively at the root surface (Fig. 2B, arrow) and colonized some intercellular spaces in the epidermis and the outer root cortex (Fig. $2 \mathrm{C})$. Bacteria were seldom seen in the inner root tissues including the inner cortex, the endodermis, and the vascular stele. A close examination of the colonized, outer root tissues showed that penetration of the epidermis by $S$. plymuthica correlated with discrete structural changes mainly characterized by a marked thickening of the epidermal wall (Fig. 2B), the occlusion of some intercellular spaces by an amorphous material that stained densely with toluidine blue (Fig. 2B), and the formation of elongated wall appositions (Fig. 2C).

In root samples from Serratia-treated plants that were challenged with $P$. ultimum, fungal colonization occurred, but to a much lesser extent than occurred in control, inoculated plants (Fig. 2D; Table 3 ). Fungal growth was mainly restricted to the outermost root tissues including the epidermis and the outer cortex (Fig. 2D; Table 3). Pathogen penetration in the outer root tissues always coincided with striking cytological changes mainly characterized by

TABLE 2. Effect of the endophytic bacterium Serratia plymuthica on the number of root lesions induced by Pythium ultimum

\begin{tabular}{lcc}
\hline & \multicolumn{2}{c}{ Number of root lesions } \\
\cline { 2 - 3 } $\begin{array}{l}\text { Days after inoculation } \\
\text { with } P \text {. ultimum }\end{array}$ & $\begin{array}{c}\text { Nonbacterized cucumber plants } \\
\text { (control) }\end{array}$ & $\begin{array}{c}\text { Bacterized } \\
\text { cucumber plants }\end{array}$ \\
\hline 1 & 0 & 0 \\
2 & $1^{\mathrm{a} \pm 0.50^{\mathrm{b}}}$ & 0 \\
3 & $8 \pm 1.5$ & 0 \\
4 & $11 \pm 1.0$ & $2 \pm 0.5$ \\
5 & $13 \pm 1.0$ & $3 \pm 1.5$ \\
6 & $15 \pm 1.5$ & $3 \pm 0.5$ \\
\hline
\end{tabular}

a The number of root lesions was determined from observations of 10 main roots per day after inoculation with $P$. ultimum.

b Values are standard errors of the mean. the elaboration of structural barriers in the regions proximal to potential fungal penetration (Fig. 2E and F). The extent and magnitude of these host responses increased as compared with those observed in root tissues from Serratia-treated plants grown in the absence of $P$. ultimum. Indeed, enlarged wall appositions were seen in the area of potential fungal spread (Fig. 2E). Such appositions formed in the reacting epidermal, and outer cortical host cells were intensely stained and were found to vary in size and shape (Fig. 2F). Another typical host reaction in the colonized area was the plugging of most intercellular spaces with a material that stained densely with toluidine blue (Fig. 2E). Wall appositions and intercellular plugging were never detected in the uncolonized root tissues beneath the invaded cell layers. Bacterial cells could be seen in some intercellular spaces but it was, most often, difficult to clearly delineate them by light microscopy.

Cytological and cytochemical observations. Severe $P$. ultimum infection developed in nearly all untreated root tissues, causing severe cell damage including cytoplasm disorganization and organelle disintegration (Fig. 3A). Primary cell walls and middle lamellae also showed marked signs of alteration characterized by a reduced electron density, even at a distance from the sites of fungal contact (Fig. 3A, arrow). Cell invasion by host wall penetration was frequently observed (Fig. 3A, double arrows).

Examination of ultrathin sections of root samples from Serratiatreated cucumber plants that were not challenged with $P$. ultimum confirmed that bacterial cells occurred in some intercellular spaces in the epidermis and the outer cortex (Fig. 3B). Bacterial colonization did not correlate with host cell wall alterations similar to those observed in Pythium-inoculated plants. Structural plant defense reactions were seen in the regions proximal to colonized intercellular spaces (Fig. 3B). The wall appositions formed at the junction between adjacent host cells were composed of a fibrillogranular material of high electron density.

A similar pattern of bacterial colonization occurred in roots from Pythium-infected cucumber plants (Fig. 3C). By contrast, the intensity of fungal colonization was reduced compared with that of nonbacterized plants. Five days after fungal inoculation, pathogen growth was restricted to the outer root tissues. Most hyphae of the pathogen (about 80\%) that penetrated the epidermis were distorted (Fig. 3C, arrows) and exhibited considerable changes including cytoplasm disorganization and, in many cases, loss of the protoplast. Intercellular spaces were frequently coated by a band of stratified, osmiophilic material with an amorphous texture (Fig. 3D). This material often extended toward the inside of the intercellular space to form droplets that interacted with hyphae of $P$. ultimum, causing an apparent mechanical pressure on the fungal wall (Fig. $4 \mathrm{~A})$. Labeling with $\beta$-1,4-exoglucanase resulted in regular deposition of gold particles over Pythium cell walls, even at a time when these walls were entirely coated by the amorphous material (Fig. $4 \mathrm{~B}$ and $\mathrm{C}$, arrows). A close examination of a large number of root sections revealed that the amorphous material could not only sur-

TABLE 3. Effect of the endophytic bacterium Serratia plymuthica on the rate and extent of Pythium ultimum colonization in cucumber root tissues, 5 days after inoculation

\begin{tabular}{|c|c|c|}
\hline \multirow[b]{2}{*}{ Root tissue } & \multicolumn{2}{|c|}{ Number of fungal hyphae per host plant cell } \\
\hline & $\begin{array}{l}\text { Nonbacterized cucumber plants } \\
\text { (control) }\end{array}$ & $\begin{array}{c}\text { Bacterized } \\
\text { cucumber plants }\end{array}$ \\
\hline Epidermis & $10.6^{\mathrm{a}} \pm 2.8^{\mathrm{b}}$ & $4.5 \pm 1.5$ \\
\hline Outer cortex & $6.8 \pm 0.3$ & $1.5 \pm 0.5$ \\
\hline Inner cortex & $5.2 \pm 1.5$ & $0.5 \pm 0.1$ \\
\hline Vascular parenchyma & $3.8 \pm 0.2$ & 0 \\
\hline Vascular stele & $2.3 \pm 0.5$ & 0 \\
\hline
\end{tabular}

a The number of fungal hyphae was determined from observations of 40 light microscope photographs of five transversally sectioned samples from five cucumber roots per treatment.

b Values are standard errors of the mean. 


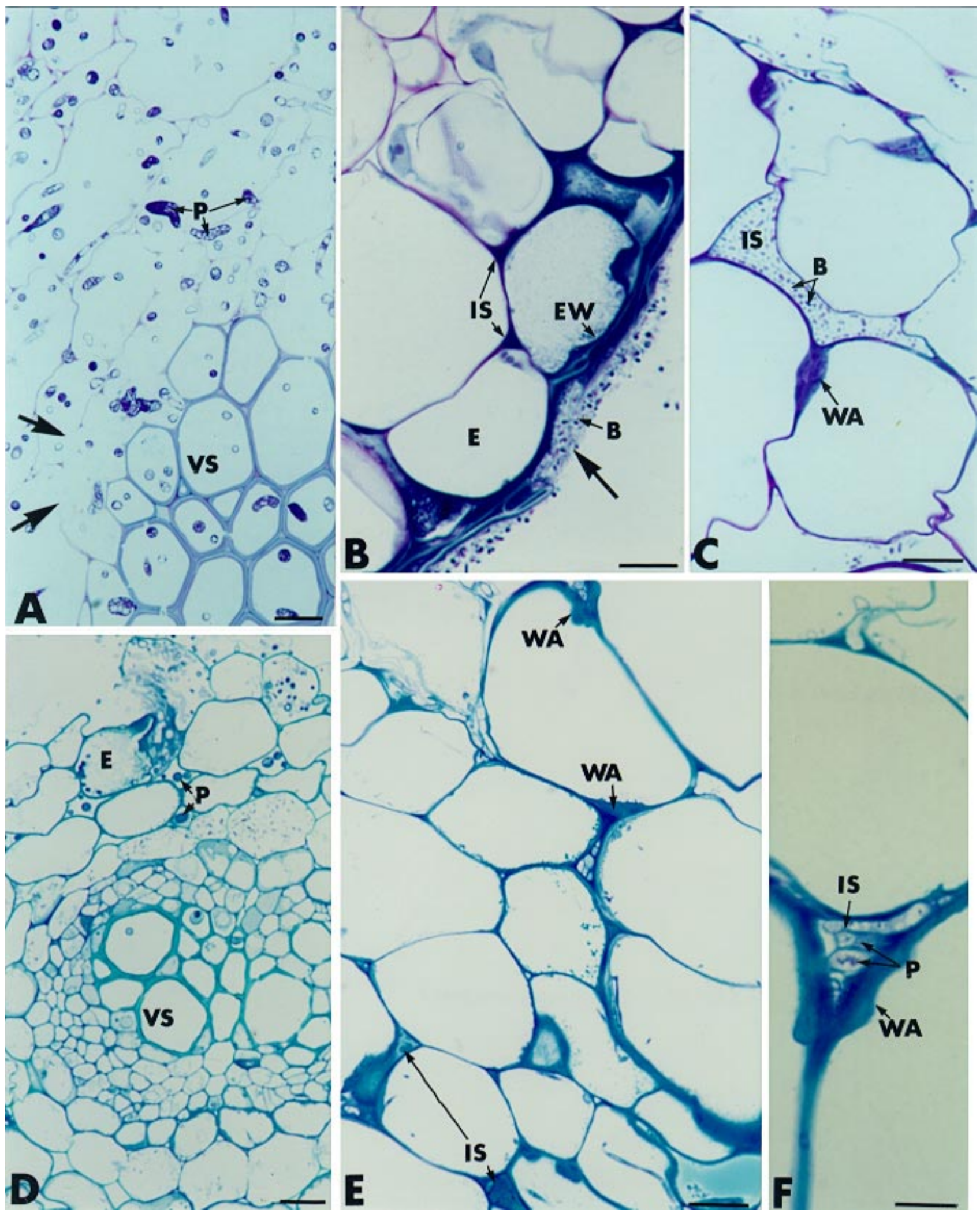

Fig. 2. Cross sections of cucumber roots. Staining with toluidine blue. A, Pythium-inoculated roots (control). Hyphae of P. ultimum (P) multiply abundantly through much of the root tissues including the vascular stele (VS). Pathogen ingress coincides with extensive cell disorganizat ion. Host cell walls are no longer discernible in massively invaded areas (arrows). Bar $=20 \mu \mathrm{m}$. B and C, Serratia-treated roots from noninoculated cucumber seedlings. The bacteria (B) grow actively at the root surface (B, arrow) and colonize some intercellular spaces (IS) in the epidermis (E) and the outer root cortex. Penetration of S. plymuthica in the root tissues correlates with a thickening of the epidermal wall (EW), the occlusion of some intercellular spaces by an amophous material, and the formation of elongated wall appositions (WA). Bars $=10 \mu \mathrm{m}$. D to F, Serratia-treated roots from Pythium-inoculated cucumber seedlings. Pythium (P) growth is restricted to the epidermis (E) and the outer cortex. Pathogen penetration in the outer root tissues coincides with the formation of enlarged wall appositions (WA). Another typical host reaction in the colonized area is the plugging of most intercellular spaces (IS) with a material that stains densely with toluidine blue. $\mathbf{D}$, Bar $=20 \mu \mathrm{m}$. $\mathbf{E}$ and $\mathbf{F}$, Bars $=10 \mu \mathrm{m}$. 


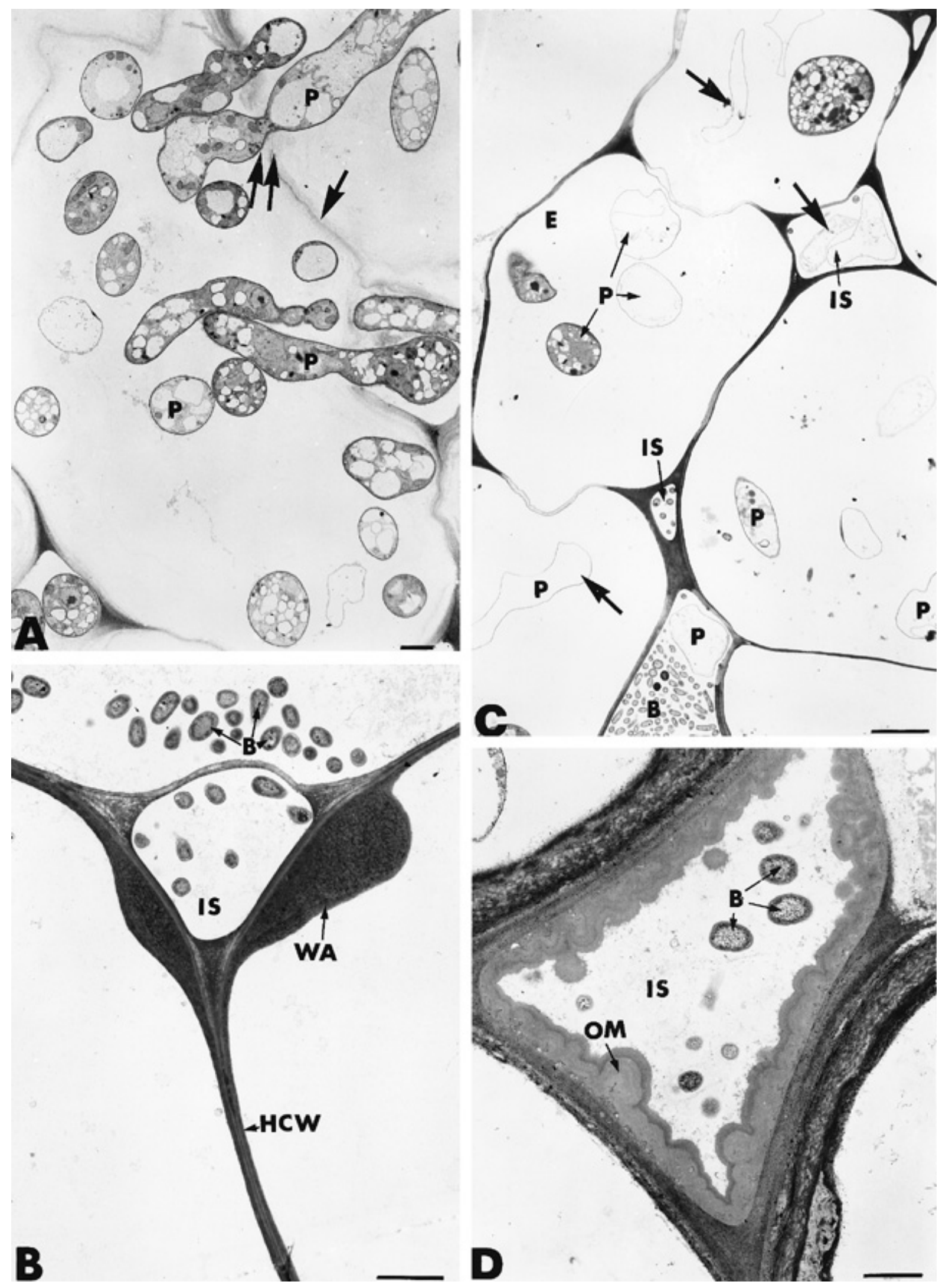

Fig. 3. Transmission electron micrographs of cross sections from cucumber roots. A, Pythium-inoculated roots. Fungal cells (P) develop abundantly in the root cortex, causing marked host cell wall alterations (arrow). Cell invasion by host wall penetration is frequently observed (double arrows). Bar $=2 \mu \mathrm{m}$. B, Serratiatreated roots from noninoculated cucumber seedlings. Bacterial cells (B) occur in some intercellular spaces in the epidermis and the outer cortex. The wall appositions (WA) formed at the junction between adjacent host cells are made of a fibrillo-granular material of high electron density. Bar $=2 \mu \mathrm{m}$. C and D, Serratiatreated roots from Pythium-inoculated cucumber seedlings. The intensity of Pythium (P) colonization is reduced compared with that of nonbacterized plants. Most hyphae of the pathogen are distorted (C, arrows) and appear as empty fungal shells. D, Intercellular spaces (IS) are frequently coated by a band of stratified, osmiophilic material (OM) with an amorphous texture. C, Bar $=2 \mu \mathrm{m}$. D, Bar $=1 \mu \mathrm{m}$. 
round the fungal cell surface (Fig. 4C) but also often infiltrate into the invading hyphae to form either an internal coating of the cell wall (Fig. 4D) or a network of polymorphic droplets in the area previously occupied by the cytoplasm (Fig. 4E). Such impregnated fungal cells were usually devoid of cytoplasm and organelles, and cell wall labeling with the gold-complexed exoglucanase was the only indication of a previously living entity (Fig. 4E).
The formation of heterogeneous wall appositions was another striking feature of reaction in bacterized plants that were challenged with P. ultimum (Fig. 5). These wall appositions were found to vary in their size and shape, ranging from hemispherical or domelike protuberances (Fig. 5A and B) to elongated, polymorphic deposits (Fig. 5C). The great heterogeneity of the wall appositions was clearly demonstrated by the presence of osmiophilic inclusions, which varied greatly in shape and even texture (Fig. 5A and C).

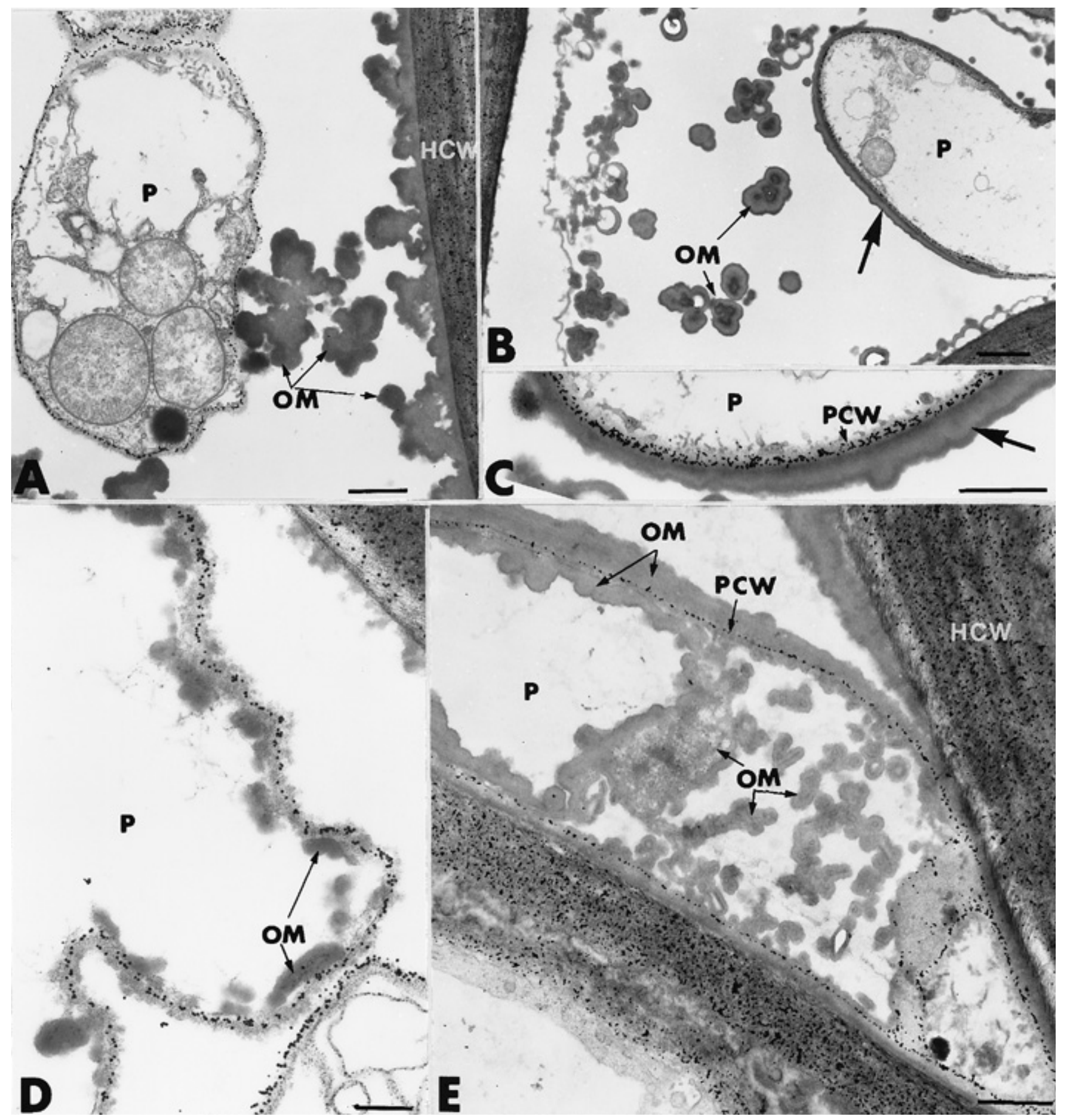

Fig. 4. Transmission electron micrographs of cross sections from Serratia-treated roots of Pythium-inoculated cucumber seedlings. A, The osmiophilic material $(\mathrm{OM})$ forms droplets that interact with hyphae of P. ultimum (P), causing an apparent mechanical pressure on the fungal wall. Labeling with the $\beta$-1,4-exoglucanase results in a regular deposition of gold particles over cell walls of both the host plant (HCW) and the fungal cells. Bar $=0.5 \mu \mathrm{m}$. B and C, The osmiophilic material $(\mathrm{OM})$ surrounds the cell wall $(\mathrm{PCW})$ of a Pythium $(\mathrm{P})$ hypha. B, Bar $=1 \mu \mathrm{m}$. C, Bar $=0.5 \mu \mathrm{m}$. D, The osmiophilic material $(\mathrm{OM})$ infiltrates a Pythium hypha $(\mathrm{P})$ and forms an internal coating. Bar $=0.25 \mu \mathrm{m}$. E, The infiltrated osmiophilic material $(\mathrm{OM})$ forms a network of polymorphic droplets in the area previously occupied by the cytoplasm. The impregnated fungal cell is devoid of cytoplasm and organelles, and cell wall (PCW) labeling with the gold-complexed exoglucanase is the only indication of a previously living entity. Bar $=0.5 \mu \mathrm{m}$. 

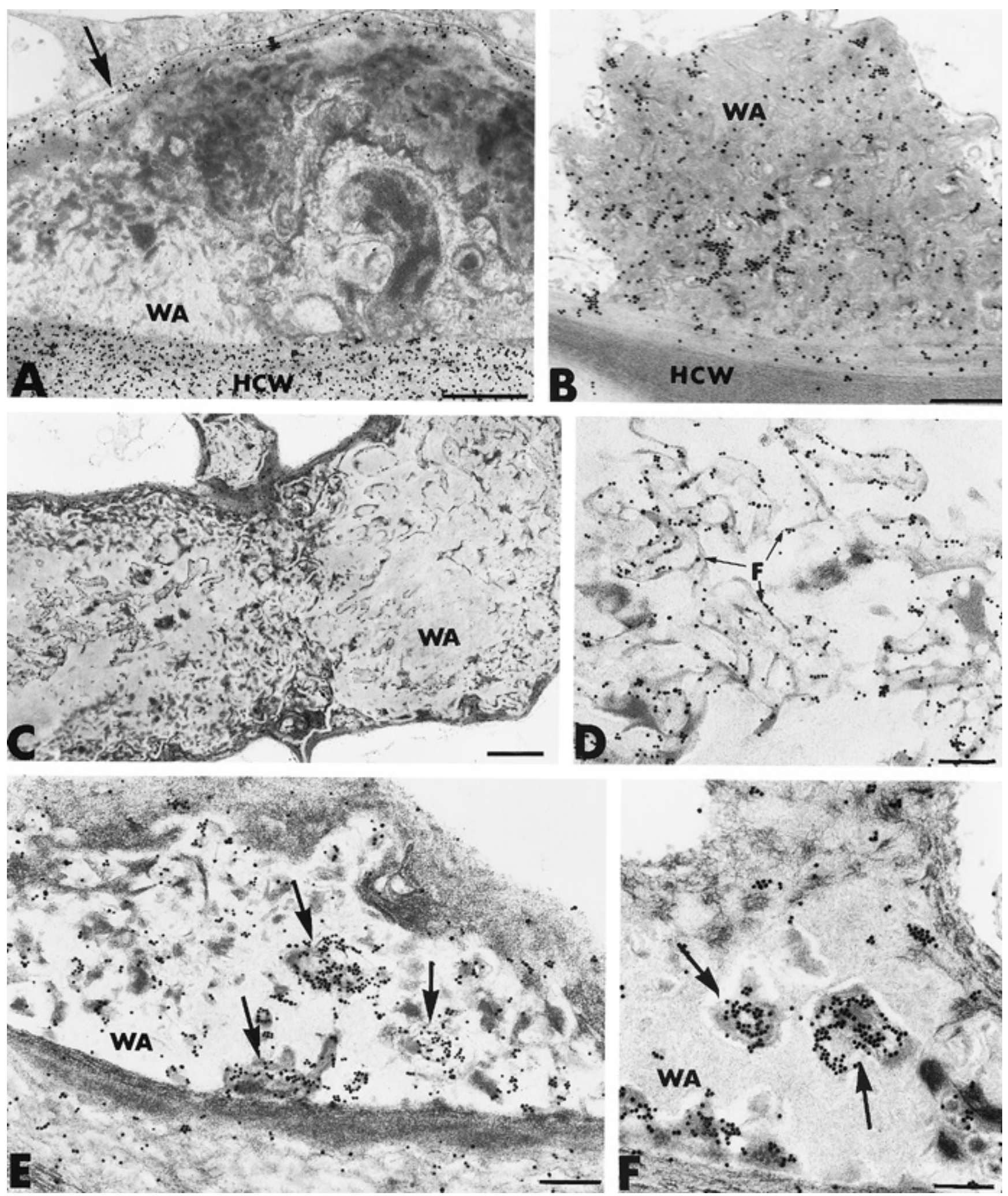

Fig. 5. Transmission electron micrographs of cross sections from Serratia-treated roots of Pythium-inoculated cucumber seedlings. Cytochemical features of the wall appositions. A, Labeling of cellulose subunits with the gold-complexed exoglucanase. An intense labeling occurs over the host cell wall $(\mathrm{HCW})$. Over the wall apposition (WA), gold particles are predominantly associated with the outermost layer (arrow). Bar $=0.5 \mu \mathrm{m}$. B, Labeling of pectic compounds with the Aplysia gonad lectin-gold complex. Gold particles are distributed throughout the wall apposition $(\mathrm{WA})$. Bar $=0.5 \mu \mathrm{m}$. $\mathbf{C}$ and $\mathbf{D}$, Labeling of galactose residues with the gold-complexed Ricinus communis agglutinin. A specific deposition of gold particles is seen over a network of intermingled fibrils (F) formed in polymorphic appositions (WA). C, Bar $=1 \mu \mathrm{m}$. D, Bar $=0.25 \mu \mathrm{m}$. E, Labeling of glucosides with the $\beta$-glucosidasegold complex. Labeling is mainly associated with the osmiophilic flecks (arrows) embedded in the electron-lucent matrix of a wall apposition (WA). Bar = $0.25 \mu \mathrm{m}$. F, Labeling of lipids with the gold-complexed lipase. Gold particles are also preferentially associated with the electron-dense inclusions (arrows). Bar $=0.25 \mu \mathrm{m}$. 
Such inclusions were usually made of an amorphous material of very high electron density (Fig. 5A). However, in some cases, they could form a network of intermingled fibrils, apparently embedded in an amorphous matrix (Fig. 5D).

As expected, application of the $\beta$-1,4-exoglucanase-gold complex to sections of Pythium-infected roots from Serratia-treated plants resulted in a heavy deposition of gold particles over the host cell walls (Fig. 5A). Labeling occurred also over the wall appositions, but it was irregularly distributed. Gold particles were predominantly associated with the outermost layer bordering the dense regions enriched with vesicles and osmiophilic inclusions (Fig. 5A, arrow). The underlying electron-lucent matrix as well as the inclusions were unlabeled. Control tests, including preincubation of the enzyme-gold complex with $\beta$-1,4-glucans prior to section labeling resulted in the absence of labeling over both the cell walls and the wall appositions (data not shown).
Following incubation with the AGL-gold complex for the localization of pectic molecules (Table 1), a few gold particles were detected over the host cell walls, while the wall appositions were intensely labeled (Fig. 5B). Gold particles were usually distributed throughout the entire multishaped appositions, although a close examination showed a predominant accumulation of labeling over the more opaque flecks accumulating on the underlying amorphous matrix (Fig. 5B). All control tests performed to assess labeling specificity resulted in a near absence of labeling (data not shown).

Incubation of ultrathin reactions with the $\mathrm{R}_{\mathrm{c}} \mathrm{A}$-gold complex for the localization of galactose residues resulted in a specific deposition of gold particles over the network of intermingled fibrils (Fig. 5D) formed in some polymorphic appositions (Fig. 5C). The electron-opaque inclusions as well as the underlying matrix were unlabeled. Specificity of this labeling pattern was assessed by the absence of gold particles over control sections (data not shown).
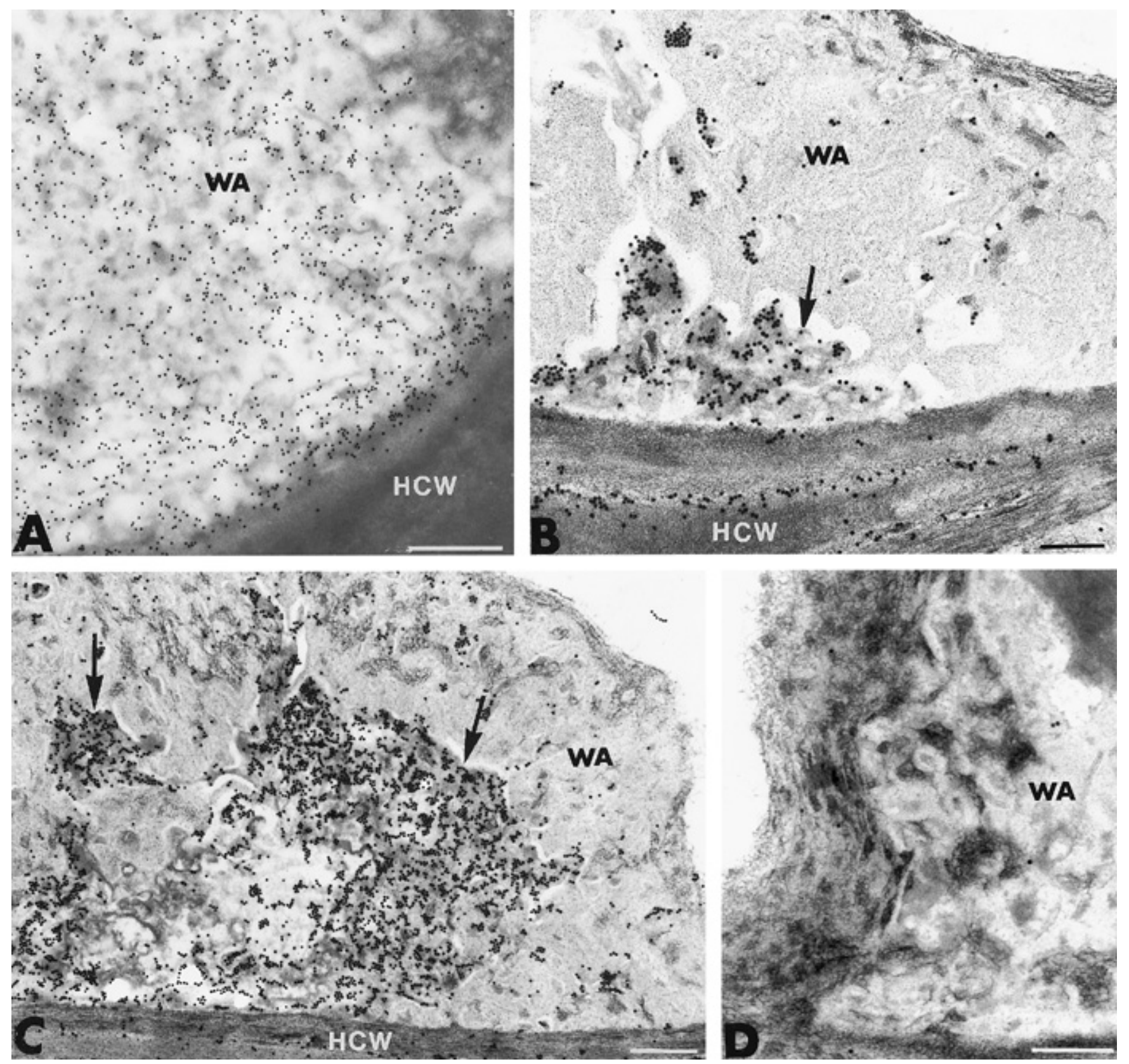

Fig. 6. Transmission electron micrographs of cross sections from Serratia-treated roots of Pythium-inoculated cucumber seedlings. Cytochemical features of the wall appositions. A, Labeling of callose with the gold-complexed $\beta-1,3$-glucanase. A heavy labeling occurs over the wall apposition (WA). Bar $=0.5 \mu \mathrm{m}$. B and C, Labeling of phenolic compounds with the gold-complexed laccase. Labeling is specifically associated with the electron-dense aggregates forming the core of most wall appositions (WA) (arrows). A few gold particles are seen over the host cell wall (HCW). Bars $=0.25 \mu \mathrm{m}$. D, Following incubation of the laccase-gold complex with sinapinic acid prior to section treatment, labeling is nearly abolished over the electron-dense inclusions of a wall apposition $(\mathrm{WA})$. Bar $=0.25 \mu \mathrm{m}$. 
When ultrathin sections were labeled with the $\beta$-glucosidase-gold complex for the localization of glucoside residues, gold particles were mainly associated with the osmiophilic inclusions and were absent over the electron-lucent matrix of wall appositions (Fig. 5E). A similar pattern of labeling was obtained upon application of the gold-complexed lipase. Gold particles were also preferentially associated with the osmiophilic material embedded in the underlying matrix (Fig. 5F). All control tests performed to assess specificity of these labelings resulted in a near absence of gold particles over sections (data not shown).

A $\beta$-1,3-glucanase, purified from tobacco plants reacting hypersensitively to Tobacco mosaic virus infection (5), was used for localizing callose, a polymer of $\beta$-1,3-glucans, in Pythium-infected cucumber roots from bacterized plants. Incubation with the goldcomplexed enzyme resulted in the deposition of a substantial number of gold particles over the wall appositions regardless their size, shape, and texture (Fig. 6A). Labeling was randomly distributed throughout the apposition, although, in some cases, it appeared preferentially associated with the electron-lucent matrix. Preincubation of the gold-complexed enzyme with laminarin prior to section labeling resulted in an absence of labeling (data not shown).

A purified laccase, produced by the white rot fungus $R$. lignosus, was used to localize lignin-like compounds and polymerized phenols in the plant material under study. Upon incubation with the gold-complexed enzyme, labeling was found to be specifically associated with the electron-dense aggregates forming the core of most wall appositions (Fig. 6B and C, arrows). In mature appositions, characterized by their compactness and high electron density, a heavy accumulation of gold particles was detected (Fig. 6C). In other appositions, labeling was restricted to the osmiophilic deposits regardless their size and shape (Fig. 6B). Incubation of the enzyme-gold complex with either ferulic acid, $p$-coumaric acid, or sinapinic acid prior to section treatment nearly abolished the labeling over the host walls and the osmiophilic deposits (Fig. 6D).

\section{DISCUSSION}

The current results provide evidence that increased resistance of the bacterized cucumber seedlings is not only associated with a decrease in the rate and extent of fungal colonization but also with an induction of structural and biochemical barriers in the host tissues. We also confirm previous microscopical observations on the potential of some bacterial endophytes to establish close contact with the root cells, penetrate the epidermis, and colonize some intercellular spaces in the outer root tissues without inducing cell damage $(9,10,14)$. A novel finding concerned the elaboration of host defense reactions beyond the sites of bacterial colonization. However, such responses were expressed with a much higher magnitude when bacterized roots were challenged with $P$. ultimum, thus providing support to the concept that a signal produced by the pathogen is essential for triggering enhanced synthesis and accumulation of defense gene products (7). In line with this concept, van Peer et al. (36) reported that enhanced phytoalexin accumulation occurred in Pseudomonas-treated carnation roots at the onset of pathogen attack. This may also explain why some authors failed to detect significant amounts of defense molecules in bacterized roots (39).

Reduction in fungal biomass and increase in hyphal structural alterations leading to the frequent occurrence of empty fungal shells were typical features of reactions observed in bacterized roots only. Whether these alterations are attributable to the creation of a fungitoxic environment associated with the synthesis and accumulation of antimicrobial compounds by the reacting host cells or simply relate to bacterial antagonism in planta remains to be biochemically investigated. However, the observation that fungal cells, trapped in the osmiophilic material accumulating in most intercellular spaces of reacting host cells, were markedly damaged at a time when the cellulose component of their cell walls was preserved favors the hypothesis of a specific plant defense reaction. Interestingly, the osmiophilic substances could extend at some distance from the coating material and apparently diffuse through the fungal cell walls without causing visible wall alterations as judged by the regular pattern of wall labeling observed upon incubation with the gold-complexed exoglucanase (Fig. 4D and E). In a recent report, Bennett et al. (17) suggested that accumulation of bright autofluorescing material within the fungus cell wall in the lettuceBremia interaction correlated with strong leakage of phenolics from the host vacuole leading to changes in ionic balance and formation of compounds with fungitoxic activity. In the current study, the osmiophilic material surrounding and penetrating Pythium hyphae failed to be consistently labeled with the gold-complexed laccase, possibly because its high degree of compactness and polymerization prevented access of the probe to its target molecules. In spite of such a negative result, the possibility that the "diffusible" substances constitute a potential source of phenolic compounds appears realistic, considering not only their texture and osmiophilic properties (34), but also the marked hyphal alterations. It is well known that the fungitoxic effect of most phenolics is attributed to their interaction with lipids or phospholipids, which causes an increase in fungal membrane permeability, pore formation, and leakage of cell contents (37). Phenolic-induced alterations in the permeability of the plasma membrane in $P$. ultimum cells may have promoted internal osmotic imbalances, leading to the observed disturbances such as plasmalemma retraction, cytoplasm aggregation, and finally complete loss of the protoplasm. While the relative contribution of phenolic compounds in the protection of cucumber against fungal attack has long been documented $(21,28)$, it is only recently that enhanced activity of some enzymes involved in the phenylpropanoid pathway (i.e., peroxidase and phenylalanine ammonia-lyase) has been monitored in Pseudomonas-treated cucumber plants (19). Although it is difficult to precisely determine from the current data the extent of the role played by the osmiophilic material in preventing and inhibiting Pythium spread in the root tissues of bacterized cucumber plants, our observations suggest that it may be involved in at least two key biological functions. First, its impregnation in the host cell walls and in the wall appositions may contribute to enhance the mechanical strength of these first defensive barriers in addition to protect them from the deleterious effect of microbial enzymes and toxins. Second, its accumulation at strategic sites (i.e., intercellular spaces) may cause inhibition of fungal growth as indicated by the distorted and degenerative aspect of fungal hyphae that were trapped, coated by, or infiltrated with this opaque material.

Another striking feature of host reaction was the formation of wall appositions at sites of potential pathogen penetration. Support for a close association between the presence of S. plymuthica in the root tissues and increased protection to Pythium invasion came from the observation that host cell wall damage in advance of invading hyphae, a typical feature of invasion monitored in nontreated plants (Fig. 3A), was absent in bacterized cucumber roots. In these roots, the apparent preservation of the cell wall architecture as well as the massive accumulation of structural barriers in areas of attempted penetration indicated that host cell walls were protected against both physical and biochemical contact with the pathogen. A substantial increase in the extent and magnitude of the cellular changes induced by $S$. plymuthica alone was observed upon challenge with $P$. ultimum. These changes were mainly characterized by a considerable enlargement of the callose-enriched wall appositions deposited onto the inner cell wall surface in the epidermis and the outer cortex. The observation that colonization by Pythium was mainly confined to the epidermis and the cortical area in bacterized cucumber root tissues correlates well with the idea that the structural deposits contribute to prevent pathogen ingress toward the vascular stele by creating a mechanical barrier.

Although qualitative, our cytochemical results provided evidence that callose, pectin, and cellulose occurred in the wall appositions. 
While callose and pectin were widely distributed over the underlying matrix of wall appositions, cellulose was mainly confined to the outermost layer of the appositions. Based on these observations, the early events leading to the development of complete appositions may involve a gradual deposition of polysaccharides such as callose and pectin between split host walls. The possibility that pectin could be, in association with callose, a major structural compound of newly formed appositions has been seldom reported. A growing body of evidence indicates that chemical bonds can be formed between lignin and pectin, leading to the elaboration of a wall-like material with reduced porosity and permeability and with decreased vulnerability to pectinolytic enzymes (30).

Glucoside residues and lipids were also detected in the wall appositions. Although these substances did not appear to be major compounds, their preferential association with the aggregated material embedded in the underlying matrix suggested that they were linked to molecules such as phenolics known to be stored in a glycosylated, nontoxic form and to have a lipoidal nature (25). In line with this hypothesis, we found that the glucoside- and lipid-enriched material was heavily labeled with the gold-complexed laccase. Subsequent infiltration of phenolics and lignin as well as lipids in the appositions may contribute to compaction of the polysaccharidic matrix composed of callose and pectin. Although the observed pattern of gold-complexed laccase labeling may not give a true picture of the extent of phenolic deposition due to the probable unavailability of some binding sites, it is clear that phenolics are key components of the structural resistance response induced by $S$. plymuthica in cucumber plants. According to our observations, the defense strategy elaborated by S. plymuthica-treated cucumber plants in response to Pythium attack appears to include, first, the accumulation of callose and pectin at or beyond the infection sites to strengthen the host cell walls and, second, the activation of secondary responses with direct incidence on the pathogen. Such responses associated with the onset of induced resistance would include the oxidation and polymerization of preexisting phenols and the synthesis of new phenolic compounds via an activation of the phenylpropanoid pathway.

Galactose residues were also among the minor polysaccharidic compounds detected in the wall appositions. However, unlike glucosides and lipids, galactose residues appeared mainly associated with a fibrillar material made of elongated strands. Whether such sugar residues reflect the deposition of newly synthesized glycoproteins, such as hydroxyproline-rich glycoproteins (HRGPs), known to accumulate at strategic sites where microbial growth is restricted (16), deserves to be further investigated. If one considers that galactose and arabinose represent the polysaccharidic moiety of HRGPs, it is reasonable that the detected galactose residues may, at least partly, be associated with these defense glycoproteins.

In conclusion, evidence is presented in this study that pretreatment with the endophytic bacterium $S$. plymuthica reduces disease incidence caused by Pythium attack by sensitizing susceptible cucumber plants to elaborate a wide range of defense mechanisms. The addition of $S$. plymuthica to plant growth media currently used in greenhouses may provide economical, prolonged protection against cucumber damping-off.

\section{ACKNOWLEDGMENTS}

The current study was supported by grants from the Natural Sciences and Engineering Research Council of Canada (NSERC), the Fonds Québécois d'Aide à la Recherche (FCAR), and the Conseil de Recherches en Pêche et en Agro-alimentaire du Québec (CORPAQ).

\section{LITERATURE CITED}

1. Albert, F., and Anderson, A. J. 1987. The effect of Pseudomonas putida colonization on root surface peroxidase. Plant Physiol. 85:537-541.

2. Bakker, P. A. H. M., van Peer, R., and Schippers, B. 1990. Specificity of siderophores and siderophore receptors in biocontrol by Pseudomonas spp. Pages 131-142 in: Biological Control of Soilborne Pathogens. D. Hornby, ed. CAB International, Wallingford, United Kingdom.

3. Bendayan, M., and Benhamou, N. 1987. Ultrastructural localization of glucoside residues on tissue sections by applying the enzyme-gold approach. J. Histochem. Cytochem. 35:1149-1155.

4. Benhamou, N. 1989. Preparation and application of lectin-gold complexes. Pages 95-143 in: Colloidal Gold, Principles, Methods, and Applications, Vol. 1. M. A. Hayat, ed. Academic Press, New York.

5. Benhamou, N. 1992. Ultrastructural detection of $\beta-1,3$-glucans in tobacco root tissues infected by Phytophthora parasitica var. nicotianae using a gold-complexed tobacco $\beta$-1,3-glucanase. Physiol. Mol. Plant Pathol. 41:351-370.

6. Benhamou, N. 1995. Ultrastructural and cytochemical aspects of the response of eggplant parenchyma cells in direct contact with Verticillium-infected vessels. Physiol. Mol. Plant Pathol. 46:321-338.

7. Benhamou, N. 1996. Elicitor-induced plant defense pathways. Trends Plant Sci. 1:233-240.

8. Benhamou, N., and Bélanger, R. R. 1998. Induction of systemic resistance to Pythium damping-off in cucumber plants by benzothiadiazole: Ultrastructure and cytochemistry of the host response. Plant J. 14:13-21.

9. Benhamou, N., Bélanger, R. R., and Paulitz, T. C. 1996. Ultrastructural and cytochemical aspects of the interaction between Pseudomonas fluorescens and Ri T-DNA transformed pea roots: Host response to colonization by Pythium ultimum Trow. Planta 199:105-117.

10. Benhamou, N., Bélanger, R. R., and Paulitz, T. C. 1996. Induction of differential host responses by Pseudomonas fluorescens in Ri T-DNAtransformed pea roots after challenge with Fusarium oxysporum f. sp. pisi and Pythium ultimum. Phytopathology 86:1174-1185.

11. Benhamou, N., Chamberland, H., Ouellette, G. B., and Pauzé, F. J. 1987. Ultrastructural localization of $\beta-1,4-D$-glucans in two pathogenic fungi and in their host tissues by means of an exoglucanase-gold complex. Can. J. Microbiol. 33:405-417.

12. Benhamou, N., Chamberland, H., Ouellette, G. B., and Pauzé, F. J. 1988. Detection of galactose in two fungi causing wilt diseases and in their host tissues by means of a gold-complexed Ricinus communis agglutinin. Physiol. Mol. Plant Pathol. 32:249-266.

13. Benhamou, N., Gilboa-Garber, N., Trudel, J., and Asselin, A. 1988. Introduction of a new lectin-gold complex for the ultrastructural localization of galacturonic acids. J. Histochem. Cytochem. 36:1403-1411.

14. Benhamou, N., Kloepper, J. W., Quadt-Hallmann, A., and Tuzun, S. 1996. Induction of defense-related ultrastructural modifications in pea root tissues inoculated with endophytic bacteria. Plant Physiol. 112:919-929.

15. Benhamou, N., Lafontaine, P. J., and Nicole, M. 1994. Induction of systemic resistance to Fusarium crown and root rot in tomato plants by seed treatment with chitosan. Phytopathology 84:1432-1444.

16. Benhamou, N., Mazau, D., Grenier, J., and Esquerré-Tugayé, M. T. 1990. Time-course study of the accumulation of hydroxyproline-rich glycoproteins in root cells of susceptible and resistant tomato plants infected by Fusarium oxysporum f.sp. radicis-lycopersici. Planta 184:196-208.

17. Bennett, M., Gallagher, M., Fagg, J., Bestwick, C., Paul, T., Beale, M., and Mansfield, J. 1996. The hypersensitive reaction, membrane damage and accumulation of autofluorescent phenolics in lettuce cells challenged by Bremia lactucae. Plant J. 9:851-865.

18. Chen, C., Bauske, E. M., Musson, G., Rodriguez-Cabana, R., and Kloepper, J. W. 1995. Biological control of Fusarium wilt on cotton by use of endophytic bacteria. Biol. Control 5:83-91.

19. Chen, C., Paulitz, T., Bélanger, R., and Benhamou, N. 1997. Inhibition of growth of Pythium aphanidermatum and stimulation of plant defense enzymes in split roots of cucumber systemically induced with Pseudomonas spp. (Abstr.) Phytopathology 87(suppl.):S18.

20. Chérif, M., Benhamou, N., and Bélanger, R. R. 1991. Ultrastructural and cytochemical studies of fungal development and host reactions in cucumber plants infected by Pythium ultimum. Physiol. Mol. Plant Pathol. 39:353-375.

21. Dean, R. A., and Kuć, J. 1987. Rapid lignification in response to wounding and infection as a mechanism for induced resistance in cucumber. Physiol. Mol. Plant Pathol. 31:69-91.

22. Dimock, M. B., Beach, R. M., and Carlson, P. S. 1989. Endophytic bacteria for the delivery of crop protection agents. Pages 88-92 in: Biotechnology, Biological Pesticides and Novel Plant-Pest Resistance for Insect Pest Management. D. W. Roberts and R. R. Granados, eds. Boyce Thompson Institute for Plant Research, Cornell University, Ithaca, NY.

23. Fiddaman, P. J., and Rossall, S. 1993. The production of antifungal volatiles by Bacillus subtilis. J. Appl. Bacteriol. 74:119-126.

24. Frens, G. 1973. Controlled nucleation for regulation of the particle size in monodisperse gold solutions. Nature (Lond.) Phys. Sci. 241:20-22.

25. Friend, J. 1979. Phenolic substances and plant diseases. Pages 577-588 in: Recent Advances in Phytochemistry: Biochemistry of Plant Phenolics, Vol. 12. T. Swain, J. B. Harbone, and C. F. van Sumere, eds. Plenum 
Press, New York.

26. Gamard, P., Sauriol, F., Benhamou, N., Bélanger, R. R., and Paulitz, T. C. 1997. Novel butyrolactones with antifungal activity produced by Pseudomonas aureofaciens strain 63-28. J. Antibiot. 50:742-749.

27. Geiger, J. P., Rio, B., Nandris, D., and Nicole, M. 1986. Laccases of Rigidoporus lignosus and Phellinus noxius; 1. Purification and some physicochemical properties. Appl. Biochem. Biotechnol. 12:121-133.

28. Hammerschmidt, R., and Kuć, J. 1982. Lignification as a mechanism for induced resistance in cucumber. Physiol. Plant Pathol. 20:61-71.

29. Kuć, J. 1987. Plant immunization and its applicability for disease control. Pages 255-274 in: Innovative Approaches to Plant Disease Control. I. Chet, ed. John Wiley \& Sons, New York.

30. Lyon, G. D., and McGill, F. M. 1989. Inhibition of polygalacturonase and polygalacturonic acid lyase from Erwinia carotovora subsp. carotovora by phenolics in vitro. Potato Res. 32:267-274.

31. McCullagh, M., Utkhede, R., Menzies, J. G., Punja, Z. K., and Paulitz, T. C. 1996. Evaluation of plant growth-promoting rhizobacteria for biological control of Pythium root rot of cucumbers grown in rockwool and effects on yield. Eur. J. Plant Pathol. 102:747-755.

32. Menzies, J. G., and Jarvis, W. R. 1994. Greenhouse cucumber: Crown and root rots, damping off. Pages 307-308 in: Diseases of Vegetable Crops in Canada. R. J. Howard, J. A. Garland, and W. L. Steaman, eds. The Canadian Phytopathological Society and the Entomological Society of Canada, Ottawa, Ontario, Canada.
33. Rankin, L., and Paulitz, T. C. 1994. Evaluation of rhizosphere bacteria for biological control of Pythium root rot of greenhouse cucumbers in hydroponic culture. Plant Dis. 78:447-451.

34. Scalet, M., Crivaletto, E., and Mallardi, F. 1989. Demonstration of phenolic compounds in plant tissues by an osmium-iodide post-fixation procedure. Stain Technol. 64:273-290.

35. Tuzun, S., and Kloepper, J. W. 1995. Practical application and implementation of induced resistance. Pages 152-168 in: Induced Resistance to Disease in Plants. R. Hammerschmidt and J. Kuć, eds. Kluwer Academic Press, Dordrecht, the Netherlands.

36. van Peer, R., Niemann, G. J., and Schippers, B. 1991. Induced resistance and phytoalexin accumulation in biological control of Fusarium wilt of carnation by Pseudomonas sp. strain WCS417r. Phytopathology 81:728734.

37. Weete, E. R. 1980. Lipid Biochemistry of Fungi and Other Organisms. Plenum Press, New York.

38. Wei, G., Kloepper, J. W., and Tuzun, S. 1994. Induced systemic resistance to cucumber diseases and increased plant growth by plant growthpromoting rhizobacteria under field conditions. Pages 70-71 in: Improving Plant Productivity with Rhizosphere Bacteria. M. H. Ryder, P. M. Stephens, and G. D. Bowen, eds. CSIRO Division of Soils, Glen Osmond, Australia.

39. Zdor, R. E., and Anderson, A. J. 1992. Influence of root colonizing bacteria on the defense responses of bean. Plant Soil 140:99-107. 